http://dx.doi.org/10.18778/1508-1117.22.04

Anna Matka

\title{
ŚLADAMI BURSZTYNOWEGO GÓRNICTWA W WOJEWÓDZTWIE POMORSKIM
}

\begin{abstract}
Zarys treści: $\mathrm{W}$ artykule przedstawiono na podstawie analizy archiwalnych materiałów kartograficznych oraz literatury polsko- i niemieckojęzycznej z okresu XVI-XXI wieku rozmieszczenie dawnych kopalni bursztynu w województwie pomorskim. Rejestr dawnych wyrobisk opracowano w oparciu o technologię GIS. W efekcie wyznaczono 32 nieznane do tej pory historyczne miejsca wydobywania bursztynu. Na podstawie badania źródeł kartograficznych: XIX i XX-wiecznych pruskich map topograficznych w skali 1:25 000 (Urmesstischblätter, Messtischblätter) i arkuszy mapy geologicznej Prowincji Prusy w skali 1:100 000 (Geologische Karte der Provinz Preußen) uszczegółowiono lokalizację 11 historycznych stanowisk górniczych. W wielu przypadkach z jednym miejscem skojarzonych było więcej kopalni bursztynu. W rezultacie badanie archiwalnych pruskich map topograficznych umożliwiło dokładną lokalizację 35 dawnych kopalni bursztynu. Dodatkowo XIX-wieczne pruskie mapy geologiczne w skali 1:100 000 wizualizują lokalizację 9 kopalni. Analiza materiałów historycznych i przeprowadzone w terenie rozpoznanie wskazuje na relikty dawnego górnictwa bursztynowego szczególnie cenne z punktu widzenia dziedzictwa kulturowego, mało znane, a przy tym dobrze zachowane w terenie. Kompleksy te po zagospodarowaniu mogą stanowić wybitnie cenne zasoby geoturystyczne województwa pomorskiego.
\end{abstract}

Słowa kluczowe: dawna kopalnia bursztynu, geostanowisko, województwo pomorskie.

\section{Wprowadzenie}

„Lubo zaś morze zdaje się być matka bursztynu, ziemia przecież $i$ w odlegtych od morza miejscach obfitym jego bywa sktadem"

K. Kluk (1781)

Bursztyn bałtycki (sukcynit) od pradziejów był znajdowany i zbierany na piaszczystych plażach Bałtyku. Dodatkowo od drugiej połowy III tysiąclecia p.n.e. bursztyn był poławiany w morzu przy pomocy specjalnych siatek umieszczonych 
na długich drągach, tzw. kaszorek (Mazurowski 1999). Nic więc dziwnego, że wielu ludziom, nawet we współczesnych czasach, bursztyn kojarzy się głównie z morzem. Surowiec bursztynowy występuje jednak w największych ilościach nie $\mathrm{w}$ morzu, lecz w głębi ziemi w osadach $\mathrm{z}$ okresu górnego eocenu, plejstocenu i holocenu. Bursztyn jest żywicą kopalną, która tworzyła się w warunkach naturalnych około 30-40 mln lat temu, w eocenie. Pierwotne nagromadzenia bursztynu występującego w północnej Polsce powstawały w bujnych lasach pokrywających obszary południowej Fennoskandii. Powalone pnie bursztynodajnych drzew przedostawały się do gruntu tworząc pokłady pierwotnych złóż bursztynu. Złoża pierwotne stopniowo ulegały erozji. Bryłki żywicy transportowane potokami i strumieniami wpadały do większej rzeki noszącej mitologiczną nazwę Eridan. W delcie tej eoceńskiej rzeki, razem z piaskiem i mułkiem osadzana była żywica bursztynodajnych drzew. $Z$ czasem materiał żywiczny przeobraził się w sukcynit. Delta Eridanu rozciągała się od Chłapowa na zachodzie po Półwysep Sambijski na wschodzie. Nagromadzenia bursztynu podlegały w kolejnych epokach geologicznych erozji i redepozycji. Największy transport bursztynonośnych osadów deltowych miał miejsce w plejstocenie, gdy sunące z północy lądolody odrywały z podłoża fragmenty bursztynonośnych osadów deltowych i przenosiły je na odległość nawet setek kilometrów. Bursztyn był transportowany w postaci kier (porwaków) glacjalnych, czyli nienaruszonych, całych pakietów osadów mechanicznie oderwanych przez lądolód od wychodni skał macierzystych. Po ustąpieniu lądolodu porwaki były osadzane i przykrywane przez młodsze osady. Kolejnym rodzajem transportu dla złóż sukcynitu były wody fluwioglacjalne. Bursztyn wleczony przez wody wypływające spod topniejących lądolodów był akumulowany wraz z piaskiem i żwirem w stożkach sandrowych przed czołem lądolodu. Późniejsza redepozycja bryłek bursztynu wiąże się z rozwojem Bałtyku w holocenie i osadzeniem bursztynu wypłukanego przez fale z osadów eoceńskich i plejstoceńskich, w zmieniających swój zasięg kopalnych i współczesnych plażach bałtyckich (Kramarska, Małka 2010; Kosmowska-Ceranowicz 2012).

Geologiczne poszukiwania złóż sukcynitu były prowadzone w czasach historycznych i współczesnych w wielu miejscach na obszarze Polski (m.in. na Kurpiowszczyźnie i Lubelszczyźnie), jednak największa uwaga była i jest kierowana na obszar województwa pomorskiego. O obecności bursztynu na Pomorzu świadczą utrwalone do dzisiejszych czasów nazwy geograficzne, przykładowo w Gdyni mamy Bursztynowe Kule, w rejonie Żukowa, gdzie do dziś znajduje się bursztyn w powierzchniowych osadach plejstoceńskich miejscowość Bursztynnik, w rejonie Bąkowa znajduje się Bursztynowa Góra, a w miejscowości Jantar co roku w okresie wakacji letnich odbywają się Mistrzostwa Świata w Poławianiu Bursztynu. W województwie pomorskim występują nagromadzenia bursztynu w osadach czwartorzędowych, redeponowane ze złóż paleogeńskich. Były one intensywnie eksploatowane w czasach historycznych w licznych kopalniach odkrywkowych i niekiedy w prymitywnych kopalniach podziemnych. Bursztyn wydobywano szczególnie intensywnie na Mierzei Wiślanej, we wschodniej, peryferyjnej 
części Pojezierza Kaszubskiego, na Równinie Słupskiej i w Borach Tucholskich. Historyczne kopalnie bursztynu rzadko kiedy dobrze zachowują się w terenie ze względu na intensywną antropopresję, a w szczególności niwelację i zabudowę terenu. Najlepiej zachowane wyrobiska po eksploatacji bursztynu występują na obszarach zalesionych, cennych pod względem przyrodniczym i krajobrazowym. Współcześnie miejsca te stanowią zabytki przyrody nieożywionej i wizualizują w terenie historię poszukiwań i eksploatacji złóż bursztynu z osadów czwartorzędowych. Ze względu na unikatowy charakter, walory naukowe, dydaktyczne i jednocześnie estetyczne, krajobrazy poeksploatacyjne złóż bursztynu powinny być objęte ochroną oraz promowane jako wartościowe produkty geoturystyczne.

Celem niniejszej pracy jest uszczegółowienie stanu wiedzy na temat historii górnictwa czwartorzędowych złóż bursztynu oraz wykonanie w technologii GIS zinwentaryzowanej mapy dawnych kopalni bursztynu. Do tej pory w celu wizualizacji rozmieszczenia dawnych kopalni bursztynu nie wykorzystywano możliwości systemów bazodanowych GIS. W pracy podjęto również próbę oceny przydatności geoturystycznej reliktów bursztynowego górnictwa, zlokalizowanych na podstawie kartometrycznych, dawnych pruskich map topograficznych, geologicznych i geologiczno-agronomicznych.

\section{Eksploatacja czwartorzędowych zlóż bursztynu w ujęciu historycznym}

Ze względu na dostępność, powszechność występowania oraz wysokie walory kolorystyczne najwcześniej rozpoznane i pozyskiwane przez człowieka były nagromadzenia bursztynu bałtyckiego akumulowane w holocenie (Kosmowska-Ceranowicz 2012). Prymitywne kopalnie bursztynu powstały na Żuławach Wiślanych już w neolicie, świadczą o tym współczesne prowadzone archeologiczne badania wykopaliskowe (Mazurowski 2003). Natomiast najstarsze przekazy pisane, dokumentujące działalność górniczą wskazują na wiek XVI jako początek wydobycia bursztynu na lądzie (Kosmowska-Ceranowicz, Pietrzak 1985). Pierwszą monografią dotyczącą bursztynu, szczególnie ciekawą, bo poruszającą tematykę miejsc występowania oraz metod pozyskiwania i wydobycia bursztynu jest dzieło Andreasa Aurifabera Succini historia z 1551 roku$^{1}$ (Małka 2014). Bursztyn był wówczas wydobywany na plażach i wydmach Mierzei Wiślanej przy pomocy łopat, a niekiedy bardziej wyrafinowanymi metodami odkrywkowymi w systemie „mokrym”. Sukcynit eksploatowano z płytkich głębokości (do ok. 3,5 m), w tym celu kopacze wykorzystywali ostro zakończone, długie drągi. Na końcówkach tych drągów umieszczano żelazne, ostre, półokrągłe, szerokie nakładki, przypo-

\footnotetext{
${ }^{1}$ Monografia A. Aurifabera należy do domeny publicznej i jest w formie cyfrowej udostępniona na stronie Kujawsko-Pomorskiej Biblioteki Cyfrowej (http://kpbc.umk.pl). Ze względu na starodawny język (wczesno-nowo-wysoko-niemiecki) i pismo (szwabacha) starodruku, dzieło to pozostaje praktycznie w Polsce nieznane.
} 
minające trochę miniaturowe łopaty ${ }^{2}$. Narzędzie to pomagało pozyskać bursztyn z nadmorskich osadów holoceńskich, składających się głównie z piasków oraz detrytusu roślinnego. Doświadczeni bursztyniarze z dużą siłą wbijali w osady drągi i następnie niejednokrotnie po dźwięku towarzyszącemu uderzeniu bursztynu o metal decydowali o dalszych poszukiwaniach i wykopywaniu płytkich kopalni. Wielokrotne wbijanie drągów, poruszanie nimi w górę i w dół służyło do rozluźniania gruntu, do którego mogła napływać płytko występująca woda gruntowa wypełniająca kopalnię. Mały ciężar bursztynu umożliwiał jego wypływanie na powierzchnię i poławianie np. przy pomocy kaszorek (Aurifaber 1551; Małka 2014). Sama Mierzeja Wiślana była wówczas określana jako ripa succini - bursztynowe wybrzeże (Kosmowska-Ceranowicz, Pietrzak 1985). W późniejszym okresie metoda ta została całkowicie zapomniana, niemniej jednak bursztyniarze wciąż powracali na bursztynodajne obszary przede wszystkim zachodniej części Mierzei Wiślanej ${ }^{3}$ Również w XVII wieku uwaga ówczesnych bursztyniarzy była skupiona przede wszystkim na Mierzei Wiślanej, a szczególnie intensywną eksploatację prowadzono w rejonie ujścia Wisły Martwej (Tylkowski 1680, fide Popiołek 2006). W XVIII wieku zwrócono uwagę na zagrożenie jakie niesie wydobycie bursztynu na tym obszarze. Eksploatacja na wydmach mierzei prowadzona bez rekultywacji terenu, powodowała niszczenie zwartej pokrywy roślinnej, przemieszczenie ruchomych wydm i straty w lasach. W następstwie tego wydobycie na Mierzei Wiślanej zostało zabronione, zezwalano jedynie na zbieranie i poławianie bursztynu. Wydobycie bursztynu na mierzei było karane aresztem i wysokimi karami pieniężnymi (Muhl 1928). Być może było to przyczyną skierowania uwagi poszukiwaczy bursztynu również na wysoczyznowe i sandrowe tereny dzisiejszego województwa pomorskiego. Zaczęły wówczas powstawać w głębi lądu liczne, małe kopalnie bursztynu. Początkowo wydobycie bursztynu było związane z przypadkowymi znaleziskami w trakcie codziennej ludzkiej działalności: wykonywania obiektów budowlanych, prac rolnych czy kopania studni, sadzawek, dołów i rowów (Hass 1930). Czasami takie nieplanowane znaleziska prowadziły do systematycznej eksploatacji bursztynu na danym terenie. Dodatkowo bursztyn może być kopaliną towarzyszącą, dlatego na sukcynit można było przypadkowo natrafić podczas wydobywania piasku, żwiru, gliny, iłu, torfu czy węgla brunatnego. Niekiedy podczas eksploatacji gliny i iłu na potrzeby lokalnej cegielni natrafiano na znaczne ilości bursztynu, przykładem jest obecna dzielnica Szadółki (Zeise, Wolff 1916), Bursztynowa Góra w rejonie Bąkowa, Klukowo w Gdańsku czy też Sucumin. Również w lasach, w wykrotach

\footnotetext{
2 Podobne narzędzia służyły do wydobycia bursztynu w morzu Bałtyckim metodami szperania (Runge 1868) oraz na lądzie przy otworach próbnych służących do rozpoznania złoża (Chętnik 1952).

${ }^{3}$ Tereny te cieszą się powodzeniem wśród bursztyniarzy również współcześnie, świadczą o tym liczne Projekty Robót Geologicznych opracowywane w celu poszukiwania bursztynu na Mierzei Wiślanej i Żuławach Wiślanych.
} 
drzew przypadkowo znajdowano osady bursztynonośne, rzadziej na mokradłach, a nawet torfowiskach (Aycke 1835). Osady bursztynonośne mogły się również odsłaniać na stokach wysoczyzny morenowej Pojezierza Kaszubskiego modelowanej przez ruchy masowe ziemi: osuwanie, obrywanie i spływanie. Tego typu przesłanki niekiedy prowadziły do rozpoczęcia działalności górniczej. Niekiedy z sukcesem, wielokrotnie powracano do tych samych miejsc, ponieważ stochastycznie, nieregularnie występujące złoża bursztynu nie zawsze udawało się wydobyć w całości, czego znakomitym przykładem jest ujście Wisły Martwej ${ }^{4}$. Wydobywane złożowe serie bursztynonośne miały bardzo zmienny charakter, występowały w formie przypadkowych, chaotycznych gniazd i żył w sypkich i spoistych osadach czwartorzędowych. W celu eksploatacji złóż najczęściej kopano płytkie szurfy, a do ich rozpoznania służyły otwory próbne. Po natrafieniu na osady bursztynonośne, które rozróżniano już na początku XVIII wieku, rozpoczynano systematyczne wydobycie. Kopaniem bursztynu trudniła się zwykle lokalna ludność, dla której było to dodatkowe, intratne, choć obarczone sporym ryzykiem źródło zysku (Aycke 1835). Wydobycie odbywało się przez cały rok (Zaddach 1869). Czasem w celu eksploatacji większych złóż dzierżawiono bursztynodajne tereny i zatrudniano doświadczonych bursztyniarzy z Gdańska (Hass 1930). W XVIII wieku na obszarze dzisiejszego województwa pomorskiego bursztyn intensywnie wydobywano w granicach dzisiejszego powiatu gdańskiego we wsiach: Kleszczewko, Różyny, Łęgowo, Bąkowo. Bursztyn eksploatowano także w dawnych wioskach: Kokoszki, Brzeźno, Klukowo, Szadółki i Rębowo, położonych obecnie na terenie dzisiejszego miasta Gdańska (m.in. Braun 1802; Berendt 1866; Samp 2009). Sukcynit był również wydobywany z osadów piaszczystych i gliniastych w dzisiejszym powiecie nowodworskim (w Sztutowie), słupskim (w okolicach Możdżanowa, Starkowa, Płaszewa i Smołdzina), bytowskim (w okolicach Miastka, Dretynia, Trzcinna), wejherowskim (Brzeźno Lęborskie) i kartuskim (Nowy Glińcz, Kartuzy). W Dretyniu i Trzcinnie eksploatację bursztynu prowadzono co najmniej od połowy XVIII wieku. Pod koniec XVIII wieku rozpoczęto eksploatację bursztynu w Borach Tucholskich. W niektórych przypadkach strefy bursztynonośne występowały na znacznych głębokościach

\footnotetext{
${ }^{4}$ Eksploatację bursztynu w rejonie ujścia Wisły Martwej prowadzono w XVII wieku (Tylkowski 1680, fide Popiołek 2006), XVIII wieku (Bock 1767), XIX wieku (Aycke 1835; Berendt 1871) i na początku XX wieku (Zeise 1908), a szczególnie intensywnie w II połowie XX wieku, kiedy to złoże bursztynu w tym rejonie zostało ponownie odkryte w trakcie budowy Portu Północnego. Obliczono wówczas jego zasoby, które oszacowano na 178 ton. Jest to do tej pory najbogatsze, znane holoceńskie złoże bursztynu (Kosmowska-Ceranowicz 2012). Również współcześnie w 2007 roku udokumentowano w pobliżu ujścia Wisły Martwej - w Przeróbce złoża bursztynu. Obecnie jest tam prowadzona legalna eksploatacja bursztynu. W 2013 roku koncesja na wydobycie bursztynu oraz kruszywa ze złoża (bursztyn jest kopaliną towarzyszącą) została udzielona firmie Baltex Minerały Sp. z o.o. (informacja od Geologa Wojewódzkiego z Urzędu Marszałkowskiego Województwa Pomorskiego).
} 
(np. w Klukowie), dodatkowo często w trakcie eksploatacji w małych kopalniach dochodziło do nacięcia poziomu wód gruntowych. Ze względu na sypki charakter osadów czwartorzędowych i związane z tym zagrożenie zasypaniem zaczęto już w XVIII wieku stosować zabezpieczenia w postaci obudowy drewnianej ścian szybików, która chroniła ściany kopalni przed osuwaniem (Braun 1802; Małka 2010).

Wiek XIX i początek XX wieku charakteryzuje niesłychanie szybki rozwój górnictwa bursztynu. Powstały wówczas kopalnie, które bazowały na rozpoznaniu geologicznym dostarczonym przez geologów i wykorzystywały technologie rewolucji naukowo-technicznej. Zdobytą przez naukowców wiedzę wykorzystywali zaradni przedsiębiorcy, którzy starali się na różne sposoby pozyskiwać bursztyn. Największe sukcesy na tym polu osiągnęli F.W. Stantien i urodzony w ubogiej żydowskiej rodzinie gdańszczanin M. Becker, którzy wspólnie założyli w 1858 roku firmę Stantien \& Becker. Firma ta prowadziła przemysłowe wydobycie bursztynu na Półwyspie Sambijskim i w Zatoce Kurońskiej oraz na terenie obecnego województwa pomorskiego w miejscowości Stegna. Złoża występujące w Polsce nie nadawały się jednak do systematycznej eksploatacji takiej, jaka była prowadzona w tym czasie na Półwyspie Sambijskim, ponieważ z reguły były to małe złoża gniazdowe. Eksploatacja odbywała się przede wszystkim metodami odkrywkowymi (Małka 2010). Niekiedy, m.in. w Gdańsku i jego okolicach stosowano zabezpieczenia ścian kopalni w postaci desek i gałęzi. Skutecznie chroniły one przed osunięciami, a dodatkowo postawione drewniane pomosty umożliwiały przerzucanie urobku. Kopalnie miały „lejkowaty” kształt, dochodziły do średnicy $25 \mathrm{~m}$ i mogły mieć taką samą głębokość (Aycke 1835). Z czasem powstały wąskie, pionowe oszalowane kopalnie szybikowe, które umożliwiały schodzenie na duże głębokości przy niższym nakładzie pracy. Oszalowanie kopalń szybikowych wykonywano z grubych bali, ułożonych na sposób holenderskich ram. Niekiedy kopalnie szybikowe drążono nawet do głębokości kilkudziesięciu metrów. W przypadku takich kopalni szybikowych stawianych ze względu na głębiej występujące gniazdowe złoża bursztynu, w ich wnętrzu budowano wielopoziomowe platformy ustawione jedna ponad drugą. Służyły one do przerzucania urobku z dna szybiku aż do powierzchni terenu (Berendt 1866; Małka 2010). W sporadycznych przypadkach, np. w okolicach jeziora Skąpego (powiat bytowski) czy na Bursztynowej Górze (powiat gdański) stosowano eksploatację podziemną: kopano szyb i przeprowadzano boczne chodniki (Zaddach 1869; Małka 2012b). Wodę gruntową i deszczową wypełniającą szybiki usuwano ręcznie (Berendt 1866). Już na początku XIX wieku próbowano zastosować pompy i węże w celu usunięcia wody gromadzącej się w wykopach podczas wydobycia. Metody te w przypadku spoistych glin zwałowych okazywały się mało skuteczne (Braun 1802). Wodę usuwano więc zwykle przy pomocy łopat i wiader. Opłacało się jednak w trakcie odwadniania nie usuwać całkowicie wody wypełniającej wyrobisko, ponieważ niski poziom wody stale utrzymywany na dnie kopalni ułatwiał bursztyniarzom eksploatację. Mały ciężar właściwy bursztynu powodował, że 
w zawiesinie piasków i żwirów opadał on wolniej od innych składników osadu. Dzięki takiemu fizycznemu oddzieleniu sukcynitu od skały płonnej łatwiejsza była jego eksploatacja. W celu efektywniejszego wydobycia poruszano osady zalegające na dnie szybików i stosowano kaszorki, którymi wyłapywano bryłki bursztynu wypływające na powierzchnię wody (Berendt 1866). W połowie XIX wieku bursztyn eksploatowano także w okolicach Łeby. Bursztyn występował na mokradłach i torfowiskach. Ze względu na specyfikę środowiska nie budowano na tym terenie kopalni, a wydobycie bursztynu polegało na długotrwałym deptaniu osadu przez mężczyzn, wyposażonych w odpowiednie ubrania ochronne. Wprawiało to $\mathrm{w}$ ruch zawiesinę, przy czym prędkość opadania bursztynu była wolniejsza od pozostałych składników osadu, wskutek czego „unosił” się on na powierzchni. Tego typu eksploatacja była prowadzona przez cały rok (Zaddach 1869). Rozpoczęte pod koniec poprzedniego wieku wydobycie w Borach Tucholskich było w XIX wieku szczególnie intensywne. W dorzeczu Brdy i Wdy zakładano wówczas liczne płytkie małe kopalnie odkrywkowe (do $6 \mathrm{~m}$ głębokości). W latach 1835-1865 wydobywano tak dużo bursztynu, że przy pracach zatrudniano jednorazowo około 200 robotników. Kopalnie bursztynu były zlokalizowane często w pobliżu lub w miejscu eksploatacji węgla brunatnego. Najbardziej bursztynodajnymi były okolice Chojnic i Czerska (Zaddach 1869). Wskutek rozwoju kopalnictwa na Sambii w drugiej połowie XIX wieku kopalnie zlokalizowane na obszarze dzisiejszego województwa pomorskiego przestały być konkurencyjne. Jednak dla lokalnej ludności wydobycie bursztynu nadal stanowiło atrakcyjną perspektywę dodatkowego dochodu.

\section{Cyfrowa mapa dawnych kopalni bursztynu}

Rozmieszczenie dawnych kopalni bursztynu opracowano w oparciu o technologię GIS. W tym celu sporządzono mapę numeryczną, w której poszczególne lokalizacje przestrzenne przedstawiono $\mathrm{z}$ wykorzystaniem wektorowego modelu danych. W końcowym efekcie powstała baza danych przestrzennych dawnych kopalni bursztynu. Taki sposób prezentacji zebranych danych umożliwia ich gromadzenie, porządkowanie, łatwe i szybkie przetwarzanie i analizę danych (np. wizualizację, wyszukiwanie, selekcję, generalizację i agregację), zarządzanie oraz prostą integrację z innymi źródłami. Baza danych przestrzennych i będąca jej wizualizacją „Cyfrowa mapa dawnych kopalni bursztynu w województwie pomorskim” (ryc. 1) zostały opracowane za pomocą oprogramowania ArcGIS v.10.2, w układzie PL-1992. Elementarnym źródłem informacji dla bazy danych przestrzennych jest katalog „Znaleziska i dawne kopanie bursztynu w Polsce” (Kosmowska-Ceranowicz 2002). Będąca kluczową częścią tego opracowania mapa analogowa została uaktualniona, poprawiona i przetworzona w technologii GIS. Docelowa mapa stanowi kompilację 40 materiałów źródłowych. W wykonaniu cyfrowej inwentaryzacji dawnych kopalni bursztynu wykorzystano literaturę polsko- 
i niemieckojęzyczną z okresu XVI-XXI wieku oraz archiwalne materiały kartograficzne znajdujące się w zbiorach Biblioteki Gdańskiej PAN, w Narodowym Archiwum Geologicznym PIG-PIB w Warszawie, w zbiorach Muzeum Ziemi PAN Warszawie, w Bibliotece Państwowej w Berlinie oraz na Wydziale Kartografii Instytutu Geografii Uniwersytetu Humboldtów w Berlinie. W pracy wykorzystano również bogate zasoby należące do domeny publicznej z repozytoriów i bibliotek cyfrowych zarówno polskich, jak i zagranicznych.

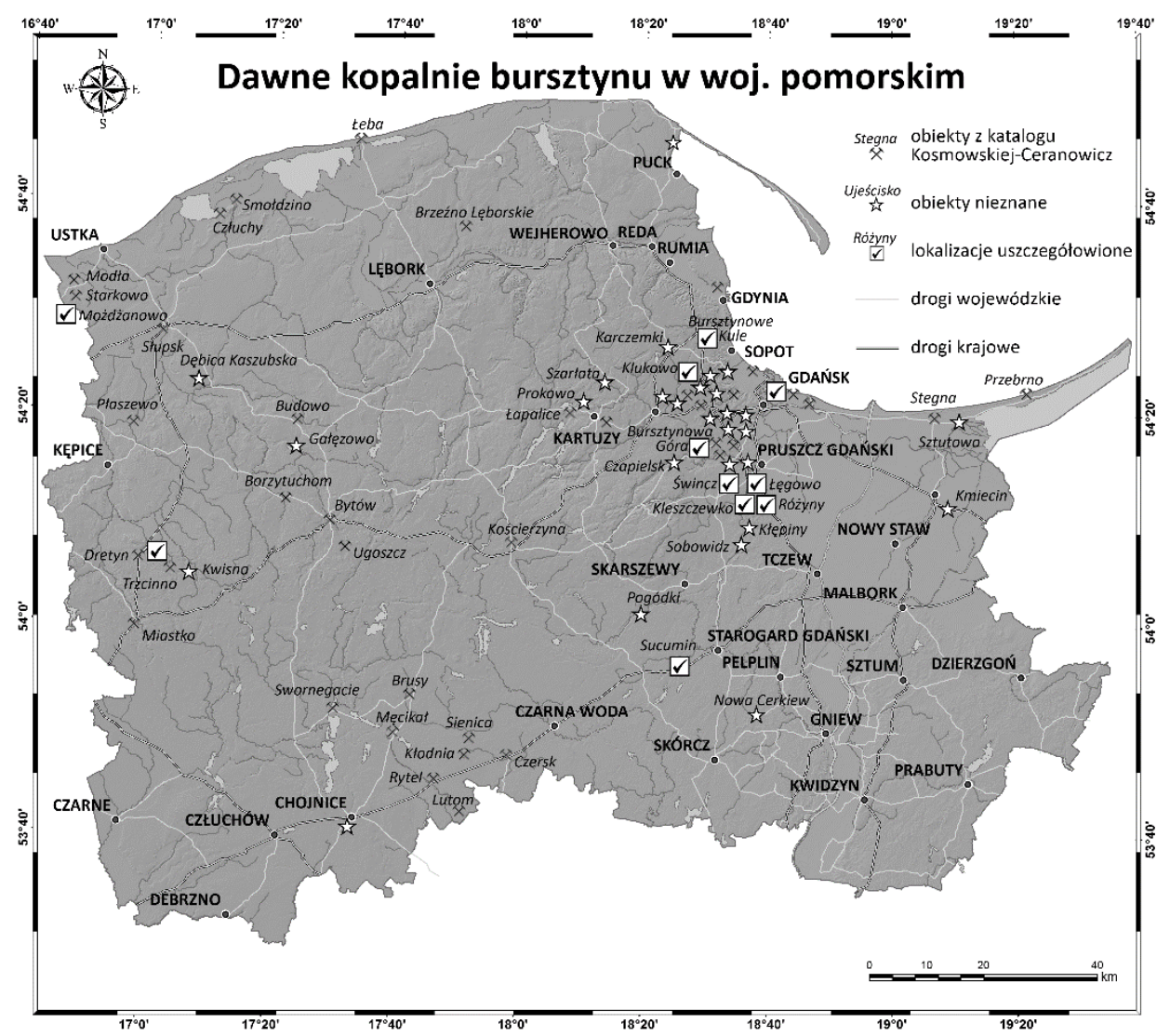

Ryc. 1. Cyfrowa mapa dawnych kopalni bursztynu w województwie pomorskim

Źródło: opracowanie własne na podstawie B. Kosmowska-Ceranowicz (2002)

Przeprowadzona przez autorkę kwerenda literatury polsko- i niemieckojęzycznej oraz historycznych materiałów kartograficznych wskazuje na lokalizacje dawnych kopalni bursztynu do tej pory nieznane. W aktualizacji mapy wykorzystano archiwalne publikacje pruskich przyrodników i geologów, w których wymieniono miejsca występowania bursztynu, w tym zweryfikowano znane wcześniej źródła danych m.in. publikacje J.C. Aycke (1835), G. Berendta (1866), E.G. Zaddacha (1869), W. Rungego (1868) oraz nieuwzględnione do tej pory 
publikacje O. Döppinga (1844), G.C. Berendta (1845), A. Menge (1850), J. Muhla (1928), U. Hassa (1930), O. Zeise i W. Wolffa (1916) oraz J. Sampa (2009). Ograniczeniem tych opracowań jest brak możliwości precyzyjnego umiejscowienia kopalni. Novum jest wykorzystanie w wizualizacji rozmieszczenia dawnych kopalni bursztynu źródeł kartograficznych z XIX i początków XX wieku, przede wszystkim materiałów w postaci rękopiśmiennej mapy Prus Schröttera-Engelhardta w skali 1:50 000 opracowanej w latach 1796-1802, rękopiśmiennej pruskiej mapy topograficznej z pierwszej połowy XIX wieku - tzw. Urmesstischblätter w skali 1:25000 i wykonanej w tej samej skali i układzie arkuszowym mapy topograficznej Messtischblätter oraz arkuszy mapy geologicznej Prowincji Prusy w skali 1:100 000 (Geologische Karte der Provinz Preußen) oraz arkuszy mapy geologiczno-agronomicznej w skali 1:25 000 (Geologische Karte von Preußen und benachbarten Bundesstaaten).

Pierwsze kartometryczne mapy, na których przedstawiono lokalizacje kopalni bursztynu to pruskie pierwotne arkusze pomiaru stolikowego - mapy topograficzne Urmesstischblätter. Ich doskonale zachowane manuskrypty nigdy nie były publikowane, dlatego zarówno treść topograficzna arkuszy tego zdjęcia, jak i ich barwny obraz kartograficzny nie są dobrze znane w naszej literaturze (Jankowska 1993; Konias 2010) i do tej pory nie były także wykorzystywane w geologii ${ }^{5}$. Urmesstischblätter mają szczegółowe, uporządkowane tematycznie objaśnienia znaków umownych. W objaśnieniach do tych map z 1818 roku i w kolejnych skonstruowanych w postaci tablic z 1848 roku określono sposób zaznaczania kopalni. Były one oznaczone symbolem graficznym w postaci owalnych, nieregularnych form, przypominających wyrobiska i dołączonym opisem oznaczającym kopalnię i typ wydobywanego w niej złoża. Tego typu sygnaturami oznaczano kopalnie piasku, żwiru, iłu i bursztynu (Bernsteingrube). Odmienne wieloboczne sygnatury stosowano dla kopalni torfu. W granicach obecnego województwa pomorskiego oryginalne, rękopiśmienne mapy topograficzne w skali 1:25000 powstawały od 1836 do 1894 roku. W północnej i peryferyjnej zachodniej części województwa przeważają arkusze starsze z lat 1836-1838. Symbolizacje tych

\footnotetext{
${ }^{5}$ Mapy topograficzne Urmesstischblätter prezentują cenne informacje geologiczne i geomorfologiczne, dlatego mogą być wykorzystywane w różnorodnych analizach czasowo-przestrzennych. Przede wszystkim mogą być używane w pomiarach kartometrycznych zmian przebiegu linii brzegowej, które służą do określenia tempa erozji i akumulacji morskiej oraz do prognozowania zmian brzegowych. Ze względu na wiarygodny obraz przemian morfologicznych przestrzeni geograficznej oparty na pomiarach geodezyjnych, archiwalne mapy topograficzne $\mathrm{z}$ różnych okresów mogą być zastosowane również w określeniu zmian powierzchni osuwisk w kolejnych przedziałach czasowych. W problematycznych przypadkach mogą posłużyć do ich identyfikacji, ponieważ rzeźba wewnątrzosuwiskowa jest często podobna do morfologii terenu historycznych wyrobisk górniczych. Ponadto archiwalne materiały kartograficzne mogą służyć do określenia zmian sieci hydrograficznej i odtworzenia rozwoju obszarów ujściowych rzek w czasach historycznych.
} 
map cechuje zastosowanie barw i użycie metody kreskowej do przedstawienia rzeźby terenu. W północno-wschodniej części obecnego województwa pomorskiego arkusze opracowano przede wszystkim w latach 1862-1867, natomiast w południowo-wschodniej zdjęcie geodezyjne wykonano później, bo w okresie 1870-1873. Na arkuszach wykonanych po 1862 roku w celu zobrazowania morfologii terenu zastosowano poziomice. Dla środkowej i północno-zachodniej części badanego obszaru (ogółem 59 arkuszy) nie opracowano arkuszy pierwotnego zdjęcia Urmesstischblätter. W niektórych miejscach, w szczególności na obszarach miejskich Gdańska i Sopotu oraz na Mierzei Wiślanej wykonano dwa, niekiedy trzy manuskrypty dla różnych lat, przykładowo dla obszaru Gdańska zdjęcie topograficzne wykonano w 1837, 1862 i 1894 roku. W niektórych przypadkach umożliwia to określenie przedziału czasowego eksploatacji bursztynu na danym obszarze. Ogółem na przeanalizowanych 143 arkuszach pomiaru stolikowego Urmesstischblätter zaznaczono lokalizację 34 kopalni bursztynu. W wielu przypadkach np. w Dretyniu i Możdżanowie w jednym miejscu znajduje się większa ilość kopalni bursztynu.

Późniejsze arkusze pomiaru stolikowego w skali 1:25000 tzw. Messtischblätter zostały opublikowane metodą litografii i w związku z tym są znane i często wykorzystywane w Polsce (Konias 2010). Na arkuszach Messtischblätter, sygnatury kopalni bursztynu pojawiają się dużo rzadziej. Można to powiązać z rozwojem myśli naukowej w zakresie geologii złóż bursztynu. W II połowie XIX wieku udokumentowano bogate złoża paleogeńskie na Półwyspie Sambijskim, w wyniku czego rozpoczęto ich intensywną, przemysłową eksploatację. Jednocześnie spada zainteresowanie złożami na Pomorzu, ponieważ badania wykazały, że występują tutaj ubogie złoża redeponowane (Zaddach 1869), czego efektem była eksploatacja bursztynu na tym terenie głównie ,sposobem gospodarczym”. Niewielka wydajność i zasobność czwartorzędowych złóż bursztynu spowodowała również spadek zainteresowania nimi ze strony instytucji państwowych. Sygnatury kopalni bursztynu na arkuszach zdjęcia topograficznego Messtischblätter są zazwyczaj pozbawione opisów, co utrudnia i niekiedy uniemożliwia ich identyfikację. Sporadycznie występują dodatkowe informacje, takie jak: „Bursztynowa Góra” (Bernsteinberg) czy „stara kopalnia szybikowa bursztynu” (Alter Bernsteinschacht), które umożliwiają rozpoznanie dawnych miejsc pozyskiwania surowca bursztynowego.

Cennym źródłem informacji dla cyfrowej mapy dawnych kopalni bursztynu są arkusze dawnych pruskich map geologicznych. Miejsca wydobycia bursztynu są wyznaczane na „Mapie geologicznej Prowincji Prusy”6 w skali 1:100 000, która

\footnotetext{
${ }^{6}$ Mapa geologiczna Prowincji Prusy (Gelogische Karte der Prowinz Preussen) była projektem bardzo innowacyjnym jak na ówczesne czasy - została opracowana jako druga tego typu mapa w Europie. Główny autor mapy Gottlieb M. Berendt (1836-1920) był jednym z pierwszych geologów zainteresowanych budową geologiczną terenów nizinnych oraz organizatorem i pomysłodawcą do dzisiaj aktualnej metodyki szczegółowego
} 
wizualizowała utwory czwartorzędowe i opisywała stratygrafię utworów holoceńskich (wówczas aluwialnych) i plejstoceńskich (wówczas dyluwialnych). Mapa ta obejmowała m.in. obszar współczesnej Polski północno-wschodniej. Dla obszaru Polski kopalnie bursztynu wyznaczono na arkuszu Delta Wisły - część północno-zachodnia (Weichsel Delta (Nordwestlicher Theil) nebst Theilen von Pommerellen und der Kassubei) i arkuszu Tczew (Dirschau). Na mapach znajdujemy informację o lokalizacji i o typie złoża: kopalnie bursztynu w osadach plejstoceńskich oznaczono sygnaturami czarnych skrzyżowanych łopat, a w osadach holoceńskich niebieskich łopat (Małka 2012a). Na pruskich mapach geologicznych wykonanych w skali 1:25 $000 \mathrm{z}$ reguły brak informacji o eksploatacji bursztynu. Niekiedy tylko w objaśnieniach do tych map znajdujemy skąpe informacje na temat pozyskiwania bursztynu. Wyjątkiem jest mapa geologiczno-glebowa w skali 1:25 000 arkusz Pruszcz Gdański z 1903 roku, na której nie tylko zaznaczono miejsca wydobycia, ale także w objaśnieniach do tej mapy znajdujemy litologiczno-stratygraficzny opis paleogeńskich osadów bursztynonośnych, tzw. „niebieskiej ziemi” (Małka 2012a). Świadczy to o aktualnej i bardzo intensywnej eksploatacji złóż bursztynu w trakcie wykonywania zdjęcia geologicznego.

W wyniku przeprowadzonej kwerendy udokumentowano lokalizację w sumie 32 nieznanych wcześniej dawnych wyrobisk bursztynu. Wraz ze stanowiskami już znanymi, zostały one przedstawione na „Cyfrowej mapie dawnych kopalni bursztynu w województwie pomorskim”. Dodatkowo badanie archiwalnych, pruskich map topograficznych w skali 1:25000 umożliwiło dokładną lokalizację 35 dawnych kopalni bursztynu, natomiast XIX-wieczne mapy geologiczne w skali 1:100 000 wizualizują lokalizację 9 kopalni. Wśród udokumentowanych 32 nieznanych do tej pory kopalni bursztynu, lokalizacje czterech miejsc: Bursztynowych Kul, Świńcza, Sucumina i okolic Dretynia zostały przedstawione na dawnych mapach. Opracowana baza danych przestrzennych dawnych kopalni bursztynu zawiera informacje o lokalizacji przestrzennej i atrybuty opisowe dawnych kopalni bursztynu. W tabeli atrybutów znajdują się informacje o źródłach pochodzenia (autor, rok), oryginalnej skali (w przypadku lokalizacji sczytanych z map) i wzmianki dotyczące m.in. sposobu eksploatacji i ilości wydobytego surowca. Baza danych może bez problemu zostać poszerzona o dodatkowe informacje, zdjęcia, skany etc. Utworzoną w systemie GIS bazę danych przestrzennych można zwizualizować w postaci mapy na podkładach w dowolnej skali i różnorodnej treści, m.in. na cyfrowym modelu wysokościowym, mapach topograficznych, mapach geologicznych i zdjęciach satelitarnych. Umożliwia to stworzenie atrakcyjnych wizualizacji rozmieszczenia dawnych kopalni bursztynu, które

kartowania geologicznego na terenach nizinnych. Niestety, jego osiągnięcia, artykuły i publikacje kartograficzne pozostają w Polsce zupełnie nieznane. $Z$ tego powodu również opracowane przez niego mapy geologiczne w skali 1:100 000 dla obszaru Polski północnej nigdy nie były wykorzystywane w trakcie opracowywania Szczegółowej Mapy Geologicznej w skali 1:50 000. 
mogą być wykorzystane w folderach popularno-naukowych, tablicach geoturystycznych i na mapach geoturystycznych. W przyszłości prezentowana mapa może być wykorzystana także w badaniach naukowych np. do geoinformacyjnego modelowania rozwoju wydobycia czwartorzędowych złóż bursztynu.

\section{Wyrobiska pogórnicze bursztynu jako cenne atrakcje geoturystyczne}

Ciekawa i mało znana historia geologiczna i górnicza towarzysząca dawnym kopalniom bursztynu czyni je cennymi atrakcjami geoturystycznymi. Ze względu na swój unikatowy charakter, wartość kulturową i naukową miejsca te są poddawane ochronie prawnej. Przeprowadzona przez autorkę kwerenda XIX i XX-wiecznych map topograficznych umożliwiła uszczegółowienie lokalizacji miejsc wymienionych we wcześniejszych opracowaniach. Dokładnie zlokalizowane na podstawie tych map dawne miejsca eksploatacji bursztynu zostały następnie zweryfikowane w terenie. Dotyczy to dzielnic Matarnia i Przeróbka w granicach administracyjnych Gdańska, dzielnicy Wielki Kack w Gdyni oraz następujących miejscowości i ich okolic: Bąkowo, Lublewo, Możdżanowo, Kleszczewko, Różyny, Łęgowo, Świńcz, Sucumin i okolice Dretynia. Spośród tych obiektów najlepiej zachowane $\mathrm{w}$ terenie są relikty dawnych robót górniczych: w Bąkowie (Bursztynowa Góra), Gdyni (Bursztynowe Kule), Możdżanowie, Kleszczewku i okolicach Dretynia. W artykule zaprezentowano trzy wybrane obiekty cechujące się dostępnością i atrakcyjnością położenia: Bursztynową Górę, Możdżanowo i Bursztynowe Kule. W celu zachowania georóżnorodności i dziedzictwa geologicznego zostały one wprowadzone do Centralnego Rejestru Geostanowisk Polski PIG-PIB. Miejsca te są lub powinny zostać poddane ochronie prawnej.

Bursztynowa Góra jest położona na południowy zachód od Gdańska, w okolicach Bąkowa. Obecnie jest najbardziej znanym, najwcześniej poddanym ochronie i najlepiej zagospodarowanym pod względem turystycznym miejscem dawnej eksploatacji bursztynu na Pomorzu. Na Bursztynowej Górze został ustanowiony na mocy Zarządzenia Ministra Leśnictwa z dnia 11.03.1954 roku rezerwat przyrody. Zagospodarowanie turystyczno-rekreacyjne wykonane z inicjatywy Lasów Państwowych obejmuje parking leśny, pieszy szlak turystyczny - żółty szlak bursztynowy umożliwiający obserwację wyrobisk pogórniczych i trasę rowerową „Wolność jest w naturze” udostępnioną w październiku 2015 roku. W pobliżu parkingu leśnego znajdują się miejsca biwakowe, gdzie ustawiono wiaty wypoczynkowe, stoły, ławki, kosze na śmieci. Szlak turystyczny jest oznakowany tablicami informacyjno-edukacyjnymi. Wokół najgłębszego wyrobiska postawiono drewniane ogrodzenie, w jego pobliżu ustawiono tablicę geoturystyczną utworzoną we współpracy Nadleśnictwa Kolbudy z Oddziałem Geologii Morza PIG-PIB. Niestety w pobliżu Bursztynowej Góry brakuje obiektów noclegowych. Najbliższą bazą noclegową jest hotel Otomin, zlokalizowany nad malowniczym, powytopiskowym jeziorem Otomińskim, leżącym na trasie szlaku pieszego 
i rowerowego. Na brzegach jeziora Otomińskiego znaleziono ślady osadnictwa pradziejowego z okresu wczesnego średniowiecza, a w Bąkowie, w pobliżu Bursztynowej Góry, wczesnośredniowieczne cmentarzysko szkieletowe (Posadzki 1972). Być może było to przyczyną powielanej w publikacjach popularno-naukowych błędnej informacji o wydobyciu sukcynitu na Bursztynowej Górze już w X wieku (m.in. Jakubowski 1971). Eksploatacja bursztynu w tym okresie nie została jednak potwierdzona badaniami archeologicznymi (Malinowski 1988), choć najprawdopodobniej surowiec bursztynowy mógł być już w pradziejach znajdowany przez okolicznych mieszkańców. Rzeźba powierzchni terenu rejonu Bursztynowej Góry została ukształtowana w ostatniej fazie najmłodszego zlodowacenia. Z ustępującego kilkanaście tysięcy lat temu lądolodu wytopiły się osady, które utworzyły malowniczy, pagórkowaty krajobraz dzisiejszej wysoczyzny morenowej. Wśród tych czwartorzędowych utworów występują pakiety utworów deltowych z bursztynem oderwane przez lądolód z macierzystych eoceńskich osadów i przeniesione w rejon Bursztynowej Góry w formie kier glacjalnych. Porwaki osiągały nawet wielometrowe rozmiary. Pakiety paleogeńskich osadów bursztynonośnych występowały nieregularnie, niekiedy pojawiały się tuż przy powierzchni terenu, kiedy indziej na głębokości kilkunastu metrów. Pierwszą pisaną wzmiankę na temat występowania bursztynu w tych okolicach zawdzięczamy G. Rzączyńskiemu, który w 1721 roku napisał, że pole w Bąkowie „ofiarowało kopaczowi kawałek bursztynu długości łokcia"7 (fide Popiołek 2006). Uwaga Rzączyńskiego dowodzi, że już wówczas w okolicy Bąkowa podczas prac polowych wykopywano bursztyn, wydobywając nawet większe bryłki. Najprawdopodobniej złoże bursztynu na Bursztynowej Górze zostało odkryte jako kopalina towarzysząca podczas wydobycia gliny na potrzeby lokalnej cegielni, która istniała w rejonie Bąkowa pod koniec XVIII wieku, świadczy o tym jej lokalizacja na rękopiśmiennej mapie Prus Schröttera-Engelhardta w skali 1:50 000 (17961802). Okres prosperity kopalni jest związany z pierwszą połową XIX wieku (Braun 1802; Aycke 1835). W 1903 roku w ramach prac kartograficznych przeprowadzono na Bursztynowej Górze badania geologiczne, które pozwoliły określić zasięg i charakter osadów. Na mapie zaznaczono również nieczynną już wówczas kopalnię bursztynu (alte Bernsteingrube). Przeprowadzone wówczas badania wykazały, że bursztyn występował w osadach paleogeńskich, w tzw. „niebieskiej ziemi”. Osady te zbudowane były z piasków kwarcowych oraz szarozielonych mułków z glaukonitem i bursztynem wieku dolnooligoceńskiego. Eksploatację na stokach Bursztynowej Góry prowadzono głównie sposobem odkrywkowym, stawiano również prymitywne kopalnie podziemne. W celu

\footnotetext{
${ }^{7}$ Niestety, okaz ten nie zachował się do naszych czasów, co związane jest z niską wytrzymałością mechaniczną tego minerału. Jedyny zachowany do dzisiejszych czasów okaz bursztynu bałtyckiego o analogicznych rozmiarach znajduje się w Muzeum Historii Naturalnej w Berlinie (Museum für Naturkunde). Jest to ważący $9750 \mathrm{~g}$ wrzecionowaty otoczak znaleziony w 1860 roku koło Kamienia Pomorskiego.
} 
wydobycia bursztynu kopano szurfy, drążono szybiki i stawiano dochodzące nawet do głębokości około $20 \mathrm{~m}$ głębokości oszalowane kopalnie wieloszybikowe. Dzisiejszy wygląd terenu może świadczyć o istnieniu również poziomych wyrobisk korytarzowych, czyli sztolni (Małka 2012b). Najgłębsze zachowane wyrobisko na Bursztynowej Górze ma kształt owalny o wymiarach 40 m x 45 m. Dłuższą osią skierowane jest na linii północ-południe. Jego głębokość wynosi 15 m, wokół brzeżnych partii szybiku usypano nadkład. Sama nazwa „Bursztynowa Góra" powstała pod koniec XIX wieku, po zaprzestaniu eksploatacji i została powszechnie przyjęta. Lokalizacja Bursztynowej Góry (Bernstein Berg) pojawia się na bardzo wielu wydawanych pod koniec XIX i na początku XX wieku mapach topograficznych w skali 1:25 000 (Messtischblätter), a także na mapach w skali 1:100 000 oraz na mapach topograficznych i turystycznych Wolnego Miasta Gdańska, które powstały po I wojnie światowej.

Kolejnym, ciekawym pod względem geoturystycznym miejscem dawnej eksploatacji bursztynu jest Możdżanowo. Miejscowość ta jest zlokalizowana na Równinie Słupskiej. Na obszarze dawnej kopalni bursztynu w Możdżanowie zatwierdzono na mocy Rozporządzenia Wojewody Pomorskiego z dnia 07.11.2001 roku stanowisko dokumentacyjne przyrody nieożywionej ${ }^{8}$. Możdżanowo znajduje się również w „Katalogu obiektów geoturystycznych w Polsce” (Słomka i in. 2006), z tego powodu jest dosyć znane i często odwiedzane, m.in. przez nauczycieli akademickich, studentów i pasjonatów geologii. Stare wyrobiska są jednak gorzej zachowane niż na Bursztynowej Górze. Dodatkowo na dawne wydobycie bursztynu nakładają się ślady współczesnej, prowadzonej w XX wieku legalnej i „dzikiej” (niekontrolowanej) eksploatacji. Nagromadzenia bursztynu bałtyckiego znajdowane w tym rejonie są podobnie jak w przypadku Bursztynowej Góry związane z transportem lodowcowym w plejstocenie. W rejonie Słupska lądolód pozostawił wiele paleogeńskich kier lodowcowych. Świadczą o tym zarówno zapiski historyczne dotyczące prowadzonych zwykle przez słupskich bursztynników poszukiwań surowca, czy też przypadkowe znaleziska w trakcie kopania studni czy prowadzenia prac budowlanych (Hass 1930). Liczne kry lodowcowe w rejonie Słupska dokumentują także współczesne badania geologiczne (m.in. Uniejewska, Nosek 1985). W Możdżanowie bursztyn znajdowany w osadach plejstoceńskich eksploatowano już w XVIII wieku. W archiwach zachowało się kilka ciekawych informacji zarówno na temat samego dysponenta kopalni, jak i prowadzonej eksploatacji. W latach prosperity (1784-1786) wydobyto tutaj wiele ton surowca. W celu eksploatacji złoża ówczesny właściciel

${ }^{8}$ Aczkolwiek lokalizacja geostanowiska przedstawiona w Geoserwisie Mapy, Generalnej Dyrekcji Ochrony Środowiska, nie pokrywa się z rzeczywistością. Zachowane wyrobiska znajdują się w obrębie zadrzewień na terenie rolnym, natomiast na mapie GDOŚ za dawną kopalnię bursztynu uznano malowniczy szpaler posadzony wzdłuż okręgu, na terenie posiadłości bursztynnika N. Kalskiego. Na zdjęciach lotniczych miejsce to, ze względu na swój kulisty kształt, przypomina wyrobisko pogórnicze bursztynu. 
kopalni Żyd Liepmann niekiedy zatrudniał nawet 100 bursztyniarzy, którzy stawiali liczne kopalnie odkrywkowe o średnicy ok. $4 \mathrm{~m}$ i dochodzili do głębokości maksymalnie 6-7 m . Po nacięciu poziomu wód gruntowych kopalnię zalała woda i Liepmann wycofał się z działalności górniczej (Deecke 1907; Małka 2010). Według niektórych źródeł przyczyną była również głęboka religijność Żyda, który nie pozwalał pracownikom wydobywać bursztyn w szabat (Braun 1802). Po tym okresie najprawdopodobniej wydobycie bursztynu w rejonie Możdżanowa nadal było kontynuowane przez innych właścicieli. W czterech czynnych kopalniach bursztyn wydobywano jeszcze w 1836 roku, co znajduje potwierdzenie na dawnej mapie topograficznej tzw. Urmesstischblatt opracowanej przez porucznika Glisczinskiego (ryc. 2; Glisczinski 1836). Mapa ta ma bardzo unikatowy charakter, istnieje tylko w formie rękopiśmiennej, nigdy nie została opublikowana. Stanowi ona najstarszy wiarygodny obraz tych obszarów powydobywczych oparty na pomiarach geodezyjnych (triangulacji). Obecnie lokalizacja jednej z dawnych, dobrze udokumentowanych kopalni bursztynu pokrywa się z obszarem promowanej przez bursztynnika N. Kalskiego ze Słupska „Zatopionej kopalni bursztynu" (http://www.kopalniabursztynu.pl/). W późniejszym okresie, w czasach bardziej współczesnych, w latach 1950-1956 wykonano w Możdżanowie głębokie wiercenia mające na celu rozpoznanie złoża, a w 1957 roku przeprowadzono w omawianym rejonie prace poszukiwawcze złóż bursztynu. W latach 1974-1975 wykonano 13 otworów do przeciętnej głębokości $20 \mathrm{~m}$ i dwa głębsze otwory M I do głębokości 173,5 m i M II do głębokości 70,3 m. Bursztyn udokumentowano w 11 otworach.

Badania wykazały, że płytko pod powierzchnią terenu na głębokości 2,5-6,0 m p.p.t. w osadach czwartorzędowych znajduje się kra glacjalna. Utwory kry reprezentowane są przez szarozielone mułki piaszczyste i piaski mułkowate $\mathrm{z}$ glaukonitem, muskowitem i bursztynem, laminowane piaskiem z iłem, miejscami nieco zwęglone, z roztartymi szczątkami roślinnymi, ksylitem i uwęglonym detrytusem. Utwory porwaka glacjalnego są silnie zaburzone glacitektonicznie i zlustrowane, z widocznymi płaszczyznami ślizgowymi. Wiek kry glacjalnej określono na dolny oligocen (Błaszak 1987), przy czym stropową część badanej kry stanowią utwory młodsze - mioceńskie. Przeprowadzone wówczas badania geologiczne pozwoliły oszacować ilość surowca na blisko 20 ton (Błaszak 1987).

Kolejnym miejscem atrakcyjnym geoturystycznie, zdecydowanie najciekawszym pod względem wielkości, liczby i stanu zachowania wyrobisk do czasów współczesnych jest dawna kopalnia bursztynu położona $\mathrm{w}$ granicach administracyjnych Gdyni, w północnej części Lasów Oliwskich, na terenach Trójmiejskiego Parku Krajobrazowego (TPK). W 2014 roku udokumentowane tu zostało przez autorkę (wspólnie z T. Szarafinem i R. Kramarską) geostanowisko

\footnotetext{
${ }^{9}$ W artykule M. Błaszak (1987) podano, że głębokość kopalni w Możdżanowie mogła mieć powyżej $20 \mathrm{~m}$, co wynika z błędnego tłumaczenia archiwalnych materiałów niemieckojęzycznych.
} 
„Bursztynowe Kule”10. Miejsce to jest praktycznie nieznane, nie podlega ochronie prawnej, nie prowadzono tam współcześnie żadnych badań geologicznych i nie zostało ono też do tej pory odpowiednio zagospodarowane pod względem geoturystycznym. Wzdłuż tego unikatowego w skali kraju obszaru powydobywczego nie przebiega także żaden z licznych szlaków turystycznych TPK.

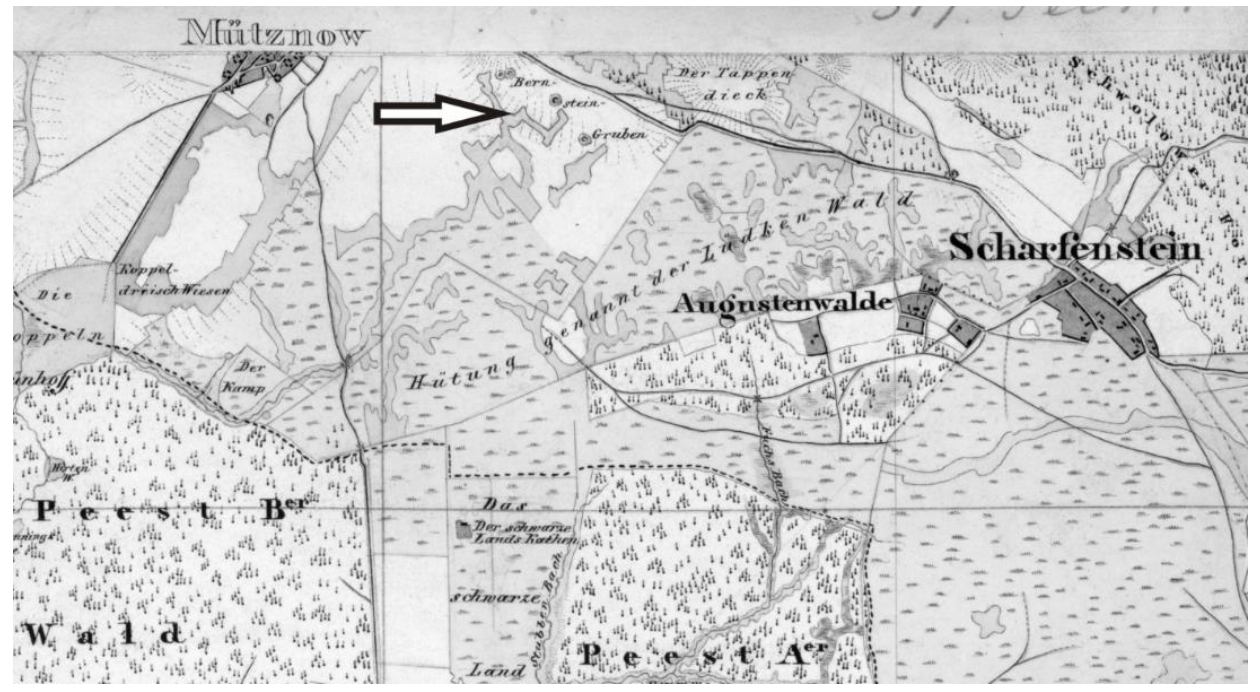

Ryc. 2. Obraz terenu w rejonie Możdżanowa (Mütznow) z zaznaczonymi kopalniami bursztynu (Bernstein Gruben; Glisczinski 1836)

Źródło: Zbiory Biblioteki Państwowej w Berlinie (sygn. N 729)

Toponim „Bursztynowe Kule” pochodzi od niemieckiego określenia „Bernstein Kaulen", zachowanego na mapach z początku XX wieku, przy czym pierwsze słowo „Bernstein” oznacza bursztyn, natomiast drugie „Kaulen” ${ }^{11}$ ma dwa różne znaczenia: 1 . kule, albo 2. kopalnie, szybiki poszukiwawcze o okrągłym kształcie. Nazwa „Bernstein Kaulen” była stosowana w XIX wieku także dla kopalni bursztynu występujących na Mierzei Wiślanej. Współcześnie, wskutek błędnego thumaczenia „Bursztynowe Kopalnie” funkcjonują jako „Bursztynowe Kule”. Podobnie jak w przypadku poprzednich lokalizacji występujące tutaj nagromadzenia bursztynu związane były z osadami porwaków (kier glacjalnych) oderwanych z utworów paleogeńskich z rejonu dzisiejszej Zatoki Gdańskiej

\footnotetext{
${ }^{10}$ Geostanowisko „Bursztynowe Kule” wprowadzono do Centralnego Rejestru Geostanowisk Polski PIG-PIB.

${ }^{11}$ Niemieckie słowo Kaule jest obecnie używane tylko we współczesnym niemieckim języku mówionym i pochodzi od XIV-wiecznej średnio-wysoko-niemieckiej formy kūle, od której wywodzi się również polskie słowo kule. Jako zaskakującą ciekawostkę można dodać, że od formy kūle pochodzi również inne słowo niemieckie Kuhle, również funkcjonujące współcześnie tylko w języku mówionym i oznaczające kopalnię.
} 
i przemieszczonych przez lodowiec w okresie ostatniego zlodowacenia. Porwaki osiągały wielometrowe rozmiary, co współcześnie odzwierciedla krajobraz pogórniczy, dokumentujący skalę eksploatacji. Wyrobiska mają z reguły owalny kształt i średnice dochodzące do $20 \mathrm{~m}$. Eksploatacja bursztynu na tym obszarze była prowadzona w pierwszej połowie XIX wieku (Aycke 1835; Zaddach 1869). Lokalizację kopalni dokumentuje arkusz mapy topograficznej w skali 1:25000 tzw. Urmesstischblatt (ryc. 3; Falckenstein 1837). Na tej unikalnej, rękopiśmiennej mapie na południe od obecnie nieistniejącego, zmeliorowanego jeziora Wielkokackiego widnieje napis oznaczający kopalnie bursztynu (auf den Bernstein Gruben). Wydobycie w rejonie Bursztynowych Kul odbywało się przede wszystkim metodą odkrywkową. Kopalnie bursztynu ze względu na występowanie $\mathrm{z}$ reguły $\mathrm{w}$ sypkich, nieskonsolidowanych utworach czwartorzędowych, miały „lejkowaty”" kształt i wymagały zabezpieczania ścian kopalni przed osunięciami ziemi drewnianą obudową (Aycke 1835). Najprawdopodobniej, podobnie jak w wielu innych miejscach w rejonie Gdańska, również w Bursztynowych Kulach stawiano kopalnie szybikowe, a w przypadku osiągnięcia bogatszych gniazd w warstwie bursztynonośnej przeprowadzano boczne chodniki (Małka 2015). W literaturze znajdują się również opisy surowca. Bursztyn wydobywany w Bursztynowych Kulach był zwykle jasno żółty, przeźroczysty, mocno zwietrzały i łamliwy (Aycke 1835). Obecnie miejsce to jest zapomniane, znane jedynie

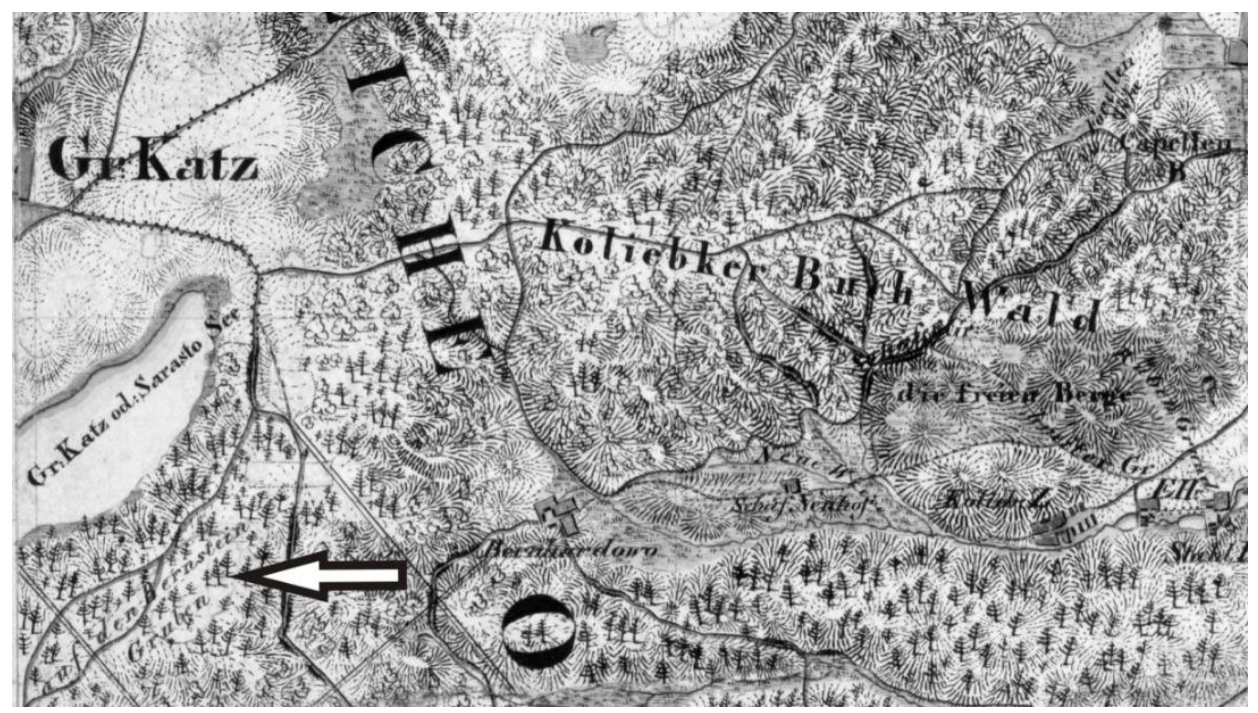

Ryc. 3. Obraz terenu w rejonie dawnego jeziora Wielkokackiego w Gdyni, z zaznaczonymi kopalniami bursztynu (auf den Bernstein Gruben; Falckenstein 1837)

Źródło: Zbiory Biblioteki Państwowej w Berlinie (sygn. N 729)

${ }^{12}$ Do dzisiaj widoczny w terenie. 
osobom szeroko zainteresowanym problematyką sukcynitu. Jednak na początku XX wieku (1919 rok) obiekt pogórniczy - „Bursztynowe Kule” cieszył się popularnością ze względu na swoje walory przyrodnicze i geologiczne. Wzdłuż tego miejsca wytyczono żółty szlak turystyczny oznakowany przez poziome, żółte paski umieszczone na drzewach. Szlak był oznaczony tablicami i wytyczony głównie na terenach leśnych, ciągnął się od dworca kolejowego w Sopocie do dworca w Oliwie.

Lokalizację kopalni dokumentują m.in. mapy leśne (Waldkarten) z lat 1901 i 1919, przy czym na tej ostatniej można prześledzić przebieg opisanego szlaku turystycznego. Niestety, współcześnie w Trójmiejskim Parku Krajobrazowym żaden z licznych szlaków turystycznych nie przebiega wzdłuż tego niezwykle ciekawego obszaru poeksploatacyjnego. Ze względu na swój unikatowy charakter, wysokie walory naukowe, dydaktyczne i jednocześnie estetyczne obszar ten powinien być objęty ochroną oraz promowany jako wartościowy produkt geoturystyczny. Miejsce to posiada indywidualną, własną historię geologiczną i górniczą odzwierciedlającą się w rzeźbie terenu. Atrakcyjne położenie „Bursztynowych Kul” w granicach miasta Gdyni i jednocześnie niezwykle czystych ekologicznie lasach Trójmiejskiego Parku Krajobrazowego, w którym występują rzadkie rośliny znane $\mathrm{z}$ dużych wymagań siedliskowych sprawia, że rejon ten można zaliczyć do niezwykle cennych, ale niewykorzystanych zasobów turystycznych Trójmiasta (Małka 2015).

\section{Wnioski}

Analiza archiwalnych materiałów kartograficznych oraz literatury z okresu XVIXXI wieku umożliwiła uszczegółowienie lokalizacji dawnych kopalni bursztynu bałtyckiego oraz wskazanie nowych, nieznanych do tej pory miejsc wydobycia tego cennego surowca. W przypadku znakomitej większości udokumentowanych na mapie dawnych kopalni, tj. dla 65 obiektów dokładność ich wyznaczenia jest mała, ponieważ miejsca te wyznaczono z literatury, co odpowiada tylko nazwom miejscowości, w których zarejestrowano wydobycie bursztynu w czasach historycznych. W 9 przypadkach lokalizację dawnych wyrobisk ustalono na podstawie arkuszy mapy topograficznej w skali 1:25000 Urmesstischblätter (Różyny, Kleszczewko, Łęgowo, osiedle Klukowo w Gdańsku, Lublewo, rejon Wisłoujścia, Możdżanowo, okolice Dretynia, Bursztynowe Kule w Gdyni) w jednym na podstawie arkusza mapy topograficznej w skali 1:25 000 Messtischblätter (Świńcz), w 4 przypadkach na podstawie arkuszy pruskiej mapy geologicznej w skali 1:100 000 (Sucumin, Lublewo, osiedle Klukowo w Gdańsku, rejon Wisłoujścia). Niekiedy lokalizacja dawnych kopalni pojawia się na wielu arkuszach różnych map, np. kopalnie w Klukowie występują zarówno na arkuszu rękopiśmiennej pruskiej mapy topograficznej w skali 1:25 000 (Urmesstischblätter), jak i arkuszu mapy geologicznej Prowincji Prusy w skali 1:100 000 (Geologische 
Karte der Provinz Preußen). Błędy ustalenia położenia dawnych kopali w tym przypadku są związane z dokładnościami poszczególnych map. Niekiedy lokalizacje dawnych kopalni były już wcześniej znane (np. Bursztynowa Góra, Możdżanowo), a kwerenda materiałów kartograficznych dodatkowo je potwierdziła.

Dawne publikacje, zwłaszcza niemieckojęzyczne, wciąż jednak pozostają nie do końca poznane w Polsce i stanowią „kopalnię wiedzy” nie tylko w kontekście podjętej przez autorkę tematyki. Przykład przeinaczenia nazwy „kopalnia” w przypadku opisanego w artykule wyrobiska pogórniczego Bursztynowe Kule wskazuje na szybkie zacieranie dawnych kopalni z pamięci ludzkiej. Również w terenie rzadko kiedy ślady po historycznej eksploatacji bursztynu zachowują się do naszych czasów. Przeprowadzony przez autorkę rekonesans terenowy na obszarach miejskich, wiejskich i leśnych wskazuje na rzadkie zachowanie reliktów dawnego górnictwa w obrębie tych dwóch pierwszych typów obszarów (miejskich i wiejskich). Zazwyczaj po wyczerpaniu złoża występującego na obszarach intensywnie użytkowanych przez człowieka, ślady po dawnych kopalniach były z czasem likwidowane, np. w celu zrównania terenu pod zabudowę (Lublewo, osiedle Klukowo w Gdańsku). Dodatkowo w niektórych miejscach, np. w rejonie Wisłoujścia, gdzie udokumentowano najbogatsze holoceńskie złoża bursztynu, (nota bene od stuleci intensywnie eksploatowane) ślady dawnego wydobycia nakładają się na wyrobiska, które powstawały i wciąż powstają współcześnie. Wyraźne wyrobiska po dawnej eksploatacji bursztynu zachowały się jedynie na obszarach leśnych (Bursztynowa Góra, Bursztynowe Kule, okolice Dretynia) i w obrębie zadrzewień śródpolnych (Możdżanowo, Kleszczewko).

Przeprowadzona przez autorkę kwerenda dawnej literatury, archiwalnych źródeł kartograficznych oraz wykonane na podstawie lokalizacji sczytanych z pruskich map topograficznych i geologicznych badania terenowe umożliwiły wytypowanie nieznanych, interesujących pod względem geoturystycznym miejsc eksploatacji sukcynitu. Szczególnie interesujące są Bursztynowe Kule w Gdyni, miejsce to ze względu na niezwykle dobrze zachowane wyrobiska poeksploatacyjne oraz korzystne położenie w obrębie Trójmiejskiego Parku Krajobrazowego powinno być koniecznie zagospodarowane pod względem geoturystycznym. Do kolejnych takich miejsc należą wyrobiska w Kleszczewku i okolicach Dretynia, jednak obiekty te są gorzej zachowane i trudniej dostępne. W przyszłości kolejne kompleksy mogą zostać wytypowane na podstawie opracowanej cyfrowej mapy dawnych kopalni bursztynu. Wiąże się to jednak z wielomiesięczną pracą $\mathrm{w}$ terenie, ponieważ $\mathrm{w}$ przypadku obiektów nie zaznaczonych na dawnych mapach znamy jedynie nazwy miejscowości, w których wydobywano w czasach historycznych bursztyn, co znacznie utrudnia ich umiejscowienie. Pewne ułatwienie $\mathrm{w}$ ich namierzeniu może stanowić analiza danych wysokościowych pochodzących z lotniczego skaningu laserowego (LIDAR) z projektu ISOK poprzedzająca właściwe prace terenowe. 


\section{LITERATURA}

Aurifaber A., 1551, Succini historia, Königsberg.

Aycke J.C, 1835, Fragmente zur Naturgeschichte des Bernsteins, Danzig.

Berendt G., 1866, Die Bernstein- Ablagerungen und ihre Gewinnung, ,Schriften der Königlichen Physikalisch-Ökonomischen Gesellschaft”, 7, Königsberg, s. 107-130.

Berendt G.C., 1845, Das Bernsteinland, [w:] Die im Bernstein befindlichen organischen Reste der Vorwelt, Berlin, s. 1-26.

Błaszak M., 1987, Bursztyn w osadach trzeciorzędowych $w$ okolicy Możḋanowa koło Stupska, „Biuletyn Państwowego Instytutu Geologicznego”, 356, Warszawa, s. 103119.

Bock F.S., 1767, Versuch einer kurzen des Preußischen Bernsteins und einer neuen wahrscheinlichen Erklärung seines Ursprunges, Zeise und Hartung, Königsberg.

Braun J.G. (red.), 1802, Über die Bernstein Gräbereien in Hinter-Pommern, Berlin.

Chętnik A., 1952, Przemyst i sztuka bursztyniarska nad Narwia, [w:] Lud, 39, KrakówPoznań, s. 355-415.

Deecke W., 1907, Geologie von Pommern, Borntraeger, Berlin.

Döpping O., 1844, Naturgeschichte und geschichtliche Mittheilungen über den Bernstein, Archiv der Pharmacie, eine Zeitschrift des Apotheker - Vereins in Deutschland, Zweite Reihe, 37(1), Hahn'sche Hofbuchhandlung, Hannover, s. 28-70.

Falckenstein, 1837, Topographische Karte, Maßstab 1:25 000, Blatt Oliva.

Glisczinski, 1836, Topographische Karte, Maßstab 1:25 000, Blatt Peest.

Hass U., 1930, Bernsteingräberei in Hinterpommern, Heimatkalender für Ostpommern auf das Jahr 1930, Stolp.

Jakubowski K., 1971, Bursztynowa Góra, [w:] Skalne zabytki, Warszawa, s. 28-29.

Jankowska M., 1993, Okoliczności powstania i sposób opracowania pruskiej mapy topograficznej z I połowy XIX wieku w skali 1:25 000, „Roczniki Akademii Rolniczej w Poznaniu", 240, s. 37-45.

Konias A., 2010, Kartografia topograficzna państwa i zaboru pruskiego od II połowy XVIII wieku do polowy XX wieku, Słupsk.

Kosmowska-Ceranowicz B. (red.), 2002, Znaleziska i dawne kopalnie bursztynu w Polsce, Biblioteka Kurpiowska im. Stacha Konwy, 158, Łomża.

Kosmowska-Ceranowicz B., 2012, Bursztyn w Polsce i na świecie, Wydawnictwo WUW, Warszawa.

Kosmowska-Ceranowicz B., Pietrzak T., 1985, Z dziejów rozwoju wiedzy o znaleziskach bursztynu i ich prezentacji na mapach dawnych $i$ współczesnych, „Prace Muzeum Ziemi”, 37, Warszawa, s. 27-60.

Kramarska R., Małka A., 2010, Bursztyn battycki, historia naturalna, złoża $i$ wydobycie, PIG-PIB, Gdańsk.

Malinowski T., 1988, Problem pozyskiwania bursztynu $w$ pradziejach $i$ we wczesnym średniowieczu na ziemiach polskich, Prace Komisji Archeologicznej, Elbląg.

Małka A., 2010, Dawne kopalnie i metody eksploatacji złóż bursztynu battyckiego, „Biuletyn Państwowego Instytutu Geologicznego", 439, Warszawa, s. 491-506.

Małka A., 2012a, Eksploatacja surowca bursztynowego z nagromadzeń czwartorzędowych w okolicach Gdańska w XIX i na poczatku XX wieku, „Prace Muzeum Ziemi”, 50, Warszawa, s. 46-55. 
Małka A., 2012b, Bursztyn w osadach późnoplejstoceńskich w rejonie Bursztynowej Góry, „Bursztynisko”, 34, Gdańsk, s. 11-14.

Małka A., 2014, Najstarszy opis metody wydobycia sukcynitu na lądzie - relacja Andreasa Aurifabera (1514-1559), „Bursztynisko”, 36, Gdańsk, s. 11-13.

Małka A. 2015, Geostanowisko powydobywcze „Bursztynowe Kule”, „Bursztynisko”, 37, Gdańsk.

Mazurowski R.F., 1999, Eksploatacja i obróbka bursztynu w okresie późnego neolitu na Żuławach, [w:] Kosmowska-Ceranowicz B. (red), Inwestigations into amber, Urbs Gyddanyzc - 1997 Gdańsk, 2-6 September 1997, Gdańsk.

Mazurowski R.F., 2003, Rola Żuław Wiślanych $w$ rozwoju prehistorycznego bursztyniarstwa $i$ kontaktów wymiennych $z$ interiorem, [w:] Kosmowska-Ceranowicz B., Gierłowski W. (red.), Bursztyn, poglady, opinie. Materiały z seminariów Amberif 1994-2004, Gdańsk.

Menge A., 1850, Geognostische Bemerkungen über die Danziger Umgegend, [w:] Neueste Schriften der Naturforschenden Gesellschaft in Danzig, Danzig, s. 1-38.

Muhl J., 1928, Die Geschichte von Stutthof, [w:] Quellen und Darstellungen zur Geschichte Westpreussens, Danzig.

Popiołek J., 2006, Bursztyn w dawnej Polsce. Antologia 1534-1900, 223, Marpress, Gdańsk.

Posadzki G., 1972, Grodzisko nad jeziorem Otomińskim, „Jantarowe Szlaki”, Biuletyn Turystyczno-Krajoznawczy Pomorza, 5(107), Gdańsk, s. 25-28.

Runge W., 1868, Der Bernstein in Ostpreussen, 70, Charisius, Berlin.

Samp J., 2009, Gdańskie dwory i pałace, Marpress, Gdańsk.

Słomka T., Kicińska-Świderska A., Doktor M., Joniec A., 2006, Katalog obiektów geoturystycznych w Polsce, 170-171, Kraków.

Uniejewska M., Nosek M., 1985, Szczegółowa mapa geologiczna Polski w skali 1:50 000 ark. Ustka (9), Wydawnictwa Geologiczne.

Zaddach E.G., 1869, Beobachtungen über das Vorkommendes Bernsteins und die Ausdehnung des Tertiärsgebirge in Westpreussen und Pommern, „Schriften der Königlichen Physikalisch-Ökonomischen Gesellschaft”, 10, Königsberg, s. 1-82.

Zeise O., Wolff W., 1916, Erläuterungen zur Geologischen Karte von Preußen und benachbarten Bundesstaaten. Blatt Danzig, Berlin.

\title{
IN THE FOOTSTEPS OF AMBER MINING IN THE POMERANIAN PROVINCE
}

\begin{abstract}
Article is based on analysis of archival cartographic materials and PolishGerman literature from the period between the $16^{\text {th }}$ and $21^{\text {th }}$ centuries. It presents the sites of old amber mines in the Pomerania Province. In total 32 new and unknown amber mines were found and the study of historical topographic maps made it possible to establish the very exact location of places mentioned in previous works. The analysis of historical materials conducted by the author points to locations of unknown, well-preserved, old extraction sites, which are valuable due to their cultural heritage. After some investment in the local infrastructure, the sites can make attractive spots in the region. The geosite of
\end{abstract}


Bursztynowe Kule' in Tricity Landscape Park is one of such places were well-preserved old amber mines are to be found. The final result of library research is the GIS 'Digital map of former amber mines in the Pomerania Province'.

Key words: former amber mine, geosite, Pomerania Province.

Mgr inż. Anna Małka Państwowy Instytut Geologiczny - Państwowy Instytut Badawczy Oddział Geologii Morza, Gdańsk 